\title{
Microcollinearity in an ethylene receptor coding gene region of the Coffea canephora genome is extensively conserved with Vitis vinifera and other distant dicotyledonous sequenced genomes
}

\author{
Romain Guyot*1, Marion de la Mare², Véronique Viader², Perla Hamon², \\ Olivier Coriton ${ }^{3}$, José Bustamante-Porras², Valérie Poncet ${ }^{2}$, \\ Claudine Campa ${ }^{2}$, Serge Hamon ${ }^{2}$ and Alexandre de Kochko²
}

Address: ${ }^{4}$ UMR GDP, IRD BP 64501, Centre IRD de Montpellier, BP 64501, Montpellier Cedex 5, France, 2 ${ }^{2}$ MR DIA-PC, IRD Génomique Comparative et Fonctionnelle de l'Adaptation, Centre IRD de Montpellier, BP 64501, Montpellier Cedex 5, France and ${ }^{3}$ UMR 118, INRA Agrocampus Rennes Amélioration des Plantes, Domaine de la Motte - BP 35327, 35650 Le Rheu cedex, France

Email: Romain Guyot* - romain.guyot@mpl.ird.fr; Marion de la Mare - marion.de-la-mare@ird.fr;

Véronique Viader - veronique.viader@mpl.ird.fr; Perla Hamon - perla.hamon@ird.fr; Olivier Coriton - olivier.coriton@rennes.inra.fr; José Bustamante-Porras - Jose.Bustamante@mpl.ird.fr; Valérie Poncet - Valerie.Poncet@ird.fr; Claudine Campa - claudine.campa@ird.fr; Serge Hamon - serge.hamon@ird.fr; Alexandre de Kochko - alexandre.dekochko@mpl.ird.fr

* Corresponding author

Published: 25 February 2009

BMC Plant Biology 2009, 9:22 doi:10.1 186/147|-2229-9-22
Received: 25 November 2008

Accepted: 25 February 2009

This article is available from: http://www.biomedcentral.com/I47I-2229/9/22

(C) 2009 Guyot et al; licensee BioMed Central Ltd.

This is an Open Access article distributed under the terms of the Creative Commons Attribution License (http://creativecommons.org/licenses/by/2.0), which permits unrestricted use, distribution, and reproduction in any medium, provided the original work is properly cited.

\begin{abstract}
Background: Coffea canephora, also called Robusta, belongs to the Rubiaceae, the fourth largest angiosperm family. This diploid species $(2 x=2 n=22)$ has a fairly small genome size of $\approx 690 \mathrm{Mb}$ and despite its extreme economic importance, particularly for developing countries, knowledge on the genome composition, structure and evolution remain very limited. Here, we report the $160 \mathrm{~kb}$ of the first C. canephora Bacterial Artificial Chromosome (BAC) clone ever sequenced and its fine analysis.
\end{abstract}

Results: This clone contains the CCEIN4 gene, encoding an ethylene receptor, and twenty other predicted genes showing a high gene density of one gene per $7.8 \mathrm{~kb}$. Most of them display perfect matches with C. canephora expressed sequence tags or show transcriptional activities through PCR amplifications on CDNA libraries. Twenty-three transposable elements, mainly Class II transposon derivatives, were identified at this locus. Most of these Class II elements are Miniature Inverted-repeat Transposable Elements (MITE) known to be closely associated with plant genes. This BAC composition gives a pattern similar to those found in gene rich regions of Solanum lycopersicum and Medicago truncatula genomes indicating that the CCEIN4 regions may belong to a gene rich region in the $C$. canephora genome. Comparative sequence analysis indicated an extensive conservation between $C$. canephora and most of the reference dicotyledonous genomes studied in this work, such as tomato (S. lycopersicum), grapevine ( $V$. vinifera), barrel medic M. truncatula, black cottonwood (Populus trichocarpa) and Arabidopsis thaliana. The higher degree of microcollinearity was found between $C$. canephora and V. vinifera, which belong respectively to the Asterids and Rosids, two clades that diverged more than II4 million years ago.

Conclusion: This study provides a first glimpse of $C$. canephora genome composition and evolution. Our data revealed a remarkable conservation of the microcollinearity between $C$. canephora and $V$. vinifera and a high conservation with other distant dicotyledonous reference genomes. Altogether, these results provide valuable information to identify candidate genes in $C$. canephora genome and serve as a foundation to establish strategies for whole genome sequencing. Future large-scale sequence comparison between $C$. canephora and reference sequenced genomes will help in understanding the evolutionary history of dicotyledonous plants. 


\section{Background}

Twenty years ago, the availability of several plant genetic maps allowed the development of the first comparative genetic mapping studies [1]. Results indicated that the marker content and order were globally conserved within plant families, between species that sometimes display huge differences in genome size and organization. Thus, macrosynteny was established within the Brassicaceae, the Fabaceae, the Solanaceae and the Poaceae families [2]. In Poaceae, the spectacular conservation of macrosynteny gave the opportunity to draw a consensus map for seven different grass genomes that diverged more than 50 million years ago [3]. In contrast to within family comparative mapping, macrosynteny appears less conserved between distantly related species belonging to distant families or different clades $[4,5]$. With such a comparison, the overall conservation of the genome organization appears scrambled by mechanisms of genome evolution such as chromosome rearrangements and genome duplications, to such an extent that the synteny was frequently limited over small genetic intervals. Recently, the increase of complete or partial genomic sequence of reference plant species from different families and the development of the BAC clones sequencing in experimental species gave the opportunity to perform direct comparisons at the genomic sequence level. Beside intra-family comparisons, microcollinearity was investigated between Arabidopsis and tomato [6,7], Arabidopsis, tomato and Capsella [8], Arabidopsis, M. truncatula, P. trichocarpa and Lotus japonicus [5] and Arabidopsis, Medicago, Populus and Cucumis melo [9]. Despite a lack of macrosynteny, a significant microcollinearity was established between these phylogenetically distant species. In addition, direct sequences comparisons allowed the detection of a complex network of microcollinearity between Arabidospis and tomato [7] and between Arabidospsis, Medicago and Populus [5] suggesting the presence of ancient segmental duplication in the Arabidopsis genome. Altogether, these analyses provided new insight into the plant genome structure and evolution.

The Rubiaceae family (Euasterids I clade) is one of the largest angiosperm families, comprising about 600 genus and more than 13,000 species and including the Gardenia, the Cinchona and the Coffea genus. The genus Coffea comprises two economically important crop species: C. arabica L. and C. canephora Pierre that account respectively for $65 \%$ and $35 \%$ of the worldwide coffee production (International Coffee Organization, http://www.ico.org). C. canephora represents a model genome in the Rubiaceae family as it has a diploid genome $(2 \mathrm{n}=2 \mathrm{x}=22)$, a relatively small genome size $(2 \mathrm{C}=1.43 \mathrm{pg})[10]$ compared to the allotetraploid genome of $\mathrm{C}$. arabica and an extensive genetic diversity [11]. Moreover, genomic resources have been recently established for $C$. canephora, such as a BAC library [12] and the availability of 55,840 C. canephora ESTs from different tissues and stages of seed development [13] to facilitate the isolation and the characterization of genes with agronomic interest. However, despite its agronomical importance, very little information concerning the composition, the structure and the evolution of the C. canephora genome is now available. Particularly, it remains unclear so far how the distantly related sequenced dicotyledonous reference genomes such as Arabidopsis, Medicago, Populus, grapevine and tomato will have a predictive value to study the genome structure and to isolate genes of interest in C. canephora. Recently, in an effort to identify factors implicated in ethylene perception during the ripening of the C. canephora berries, several ethylene receptors and transcription factors genes were isolated [14-16]. One of them called CcEIN4 was identified on an isolated BAC clone [15].

In this study, we present the complete sequencing of the C. canephora BAC clone 46C02, carrying the CCEIN4 gene. Sequence analysis of the $160 \mathrm{~kb}$ of the BAC indicates a high density of active genes and few transposable elements. Sequence comparisons reveal a high microcollinearity between the C. canephora BAC clone and most of the current dicotyledonous sequenced genomes that diverged 114 to 125 Million Years Ago (MYA).

\section{Results \\ The C. canephora BAC clone $46 \mathrm{CO} 2$ carries the mono locus CcEIN4 gene}

The CCEIN4 gene, used as a probe for hybridization, revealed eight positive BAC clones on the high-density filters of the C. canephora BAC library. Among these clones, the BAC clone 46C02 was randomly chosen for further analyses. Low-pass sequencing of about 70 sub-clones from BAC 46C02 suggested the presence of several potential coding regions and sequence analyses confirmed the presence of the CcEIN4 gene. Finally, pulsed field analysis indicated the presence of a large insert of about $160 \mathrm{~kb}$ length.

Segregation analysis of the EIN4 marker, in the interspecific back-cross progeny $[($ C. canephora $\times$ C. heterocalyx $) \times$ C. canephora], showed mono locus Mendelian segregation pattern (Figure 1A). In addition, in situ BAC hybridizations (BAC-FISH) showed a unique and chromosomespecific sub-terminal/terminal labeling for 46C02 in a non-45S rDNA chromosome pair (Figure 1B).

\section{Sequence composition and organization of BAC $46 C 02$ Genes}

The C. canephora BAC, containing the CcEIN4 gene, was fully sequenced. The 160,404 bp of the BAC clone $46 \mathrm{C0} 2$ (GenBank accession EU164537) showed an overall 


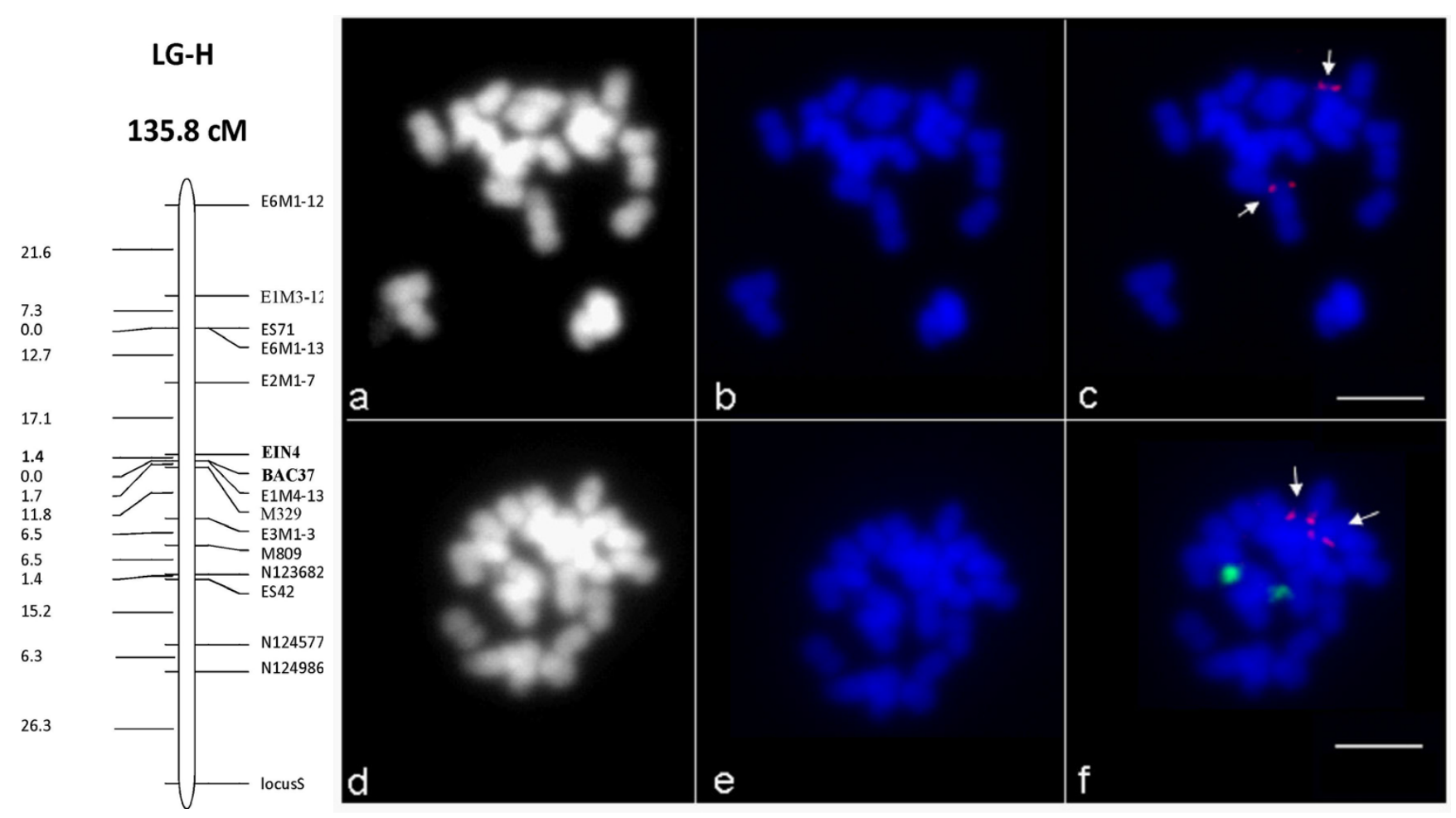

Figure I

Genetic and physical mapping of BAC 46C02. A. Genetic mapping of markers located onto the BAC 46C02. Linkage Group H $(\mathrm{LG} \mathrm{H})$ from the $[(C$. canephora $\times$ C. heterocalyx $) \times C$. canephora] genetic map, showing the location of the EIN4 gene and BAC-37 microsatellites. B. Physical mapping by BAC-FISH on mitotic chromosomes from . (a-c) Fluorescence in situ hybridization (FISH) signals of the BAC clone 46C02 (red signals) on mitotic metaphase chromosomes of $C$. canephora (genotype BB 62). Fluorescence signals of the BAC clone are indicated with arrows. (d-f) Double FISH with the BAC clone 46C02 (red signals) and rDNA (green signals). Chromosomes were counterstained with DAPI (blue). Bars represent $5 \mu$ m. (a and $d)$, grayscale images of the same preparation as in $b$ and $e$.

$37.3 \%$ GC content and a GC content of the predicted coding sequences (CDS) of $45.7 \%$.

$A b$ initio predictions gave 30, 43 and 55 predicted gene structures with the FGENESH gene finder trained respectively for grapevine, tomato and tobacco gene models. We evaluated the accuracy of the predictions by comparative analysis between predicted gene structures and results of similarity searches of the BAC sequence against proteins and nucleotides sequences databases. Manual controls between $a b$ initio predictions and sequences alignments suggest numerous incongruities. Over prediction of inaccurate gene models, imprecise exons, mainly located at the 3 ' ends of predicted genes supported by EST alignments and inexact predictions of exon-intron boundaries (start, stop and splicing sites) was observed. These results indicate a relatively low quality of the $a b$ initio predictions in C. canephora when using training set of gene models from different eudicots model genomes. In absence of available $C$. canephora training set, we conclude that prediction of the gene structures may be used cautiously.
In total, 21 genes were identified and validated by sequence alignments, giving an overall gene density of about one gene per $7.8 \mathrm{~kb}$, considering the partial gene (g1) that covers the 5' part of the BAC insert (Table 1; Figure 2). Similarities with plant Expressed Sequence Tag sequences (EST) were found for the 21 identified genes (Table 1). Eight genes $(g 2, g 4, g 5, g 6, g 7, g 14, g 15$ and $g 16)$ have almost perfect matches with $C$. canephora ESTs and mRNA, with sequence identities higher than 97\%, suggesting that these genes are expressed. All the remaining genes have significant matches with plant ESTs (> 70\% identity). On the 10 genes analyzed, seven $(g 3, g 7, g 8, g 9$, $g 10, g 11$ and $g 13)$ showed PCR amplifications on two $C$. canephora cDNA libraries (Table 1 ). For genes $g 3$ and $g 7$, sequencing of PCR products allowed the fine determination of the gene model and then the re-annotation of the gene predictions. Gene $6(g 6)$ encodes an ethylene receptor with a high sequence identity (85.7\%) with the tomato ethylene receptor neverripe gene (ETR5 accession AY600439, [17]). This gene, called CcEIN4 (position from 36174 to $40482 \mathrm{bp}$ ), was previously cloned and analyzed 

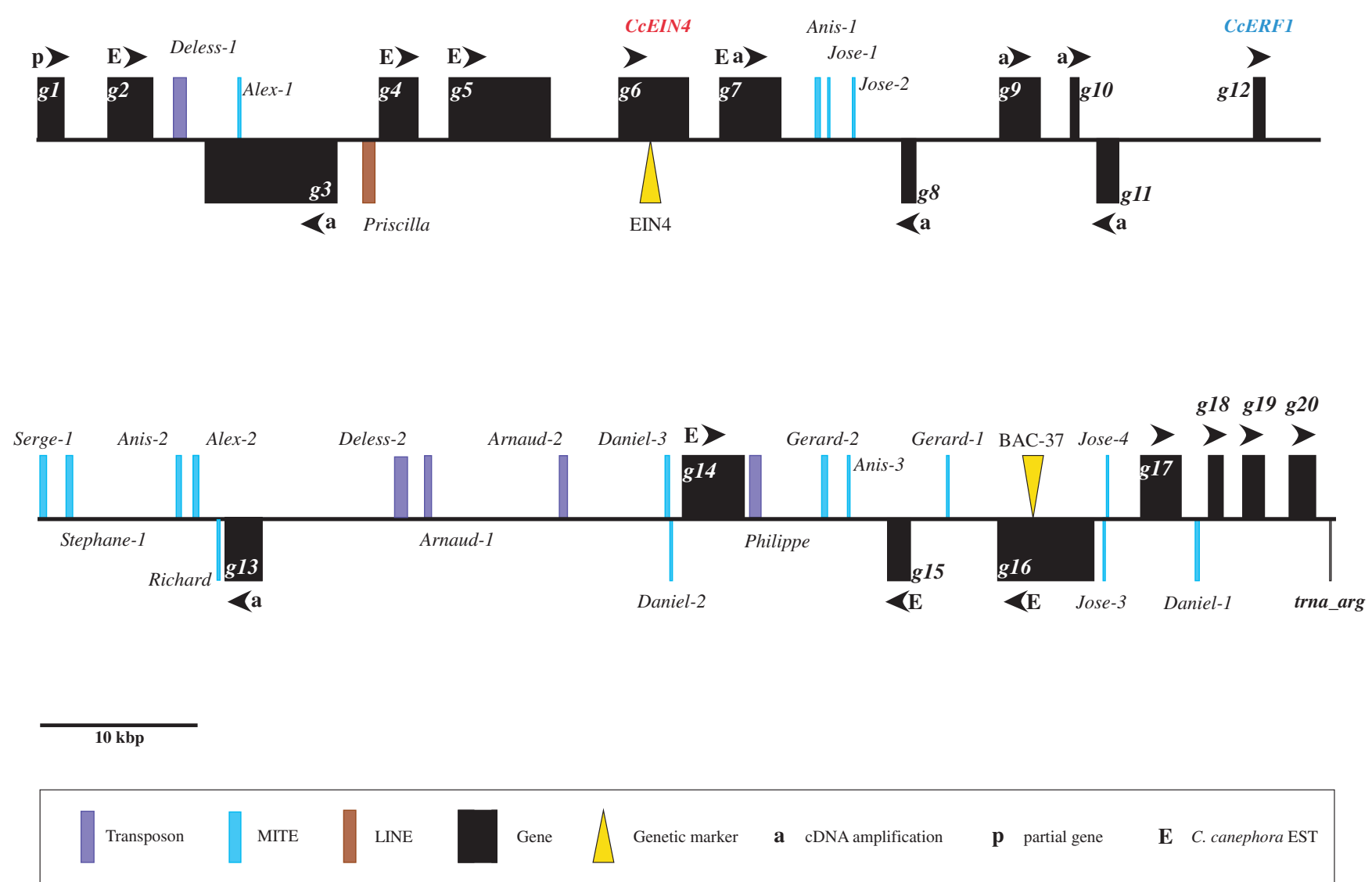

Figure 2

Physical map of the 160,404 bp sequence of the coffee BAC 46C02. Black boxes represent identified coding regions and arrowheads indicate transcriptional orientation of genes. The CCEIN4 gene is indicated in red. Colored boxes represent identified transposable elements as follows: violet for transposons, blue for MITEs and brown for LINE. Markers used for genetic mapping on LGH (EIN4 and BAC-37) are indicated by a yellow triangle. P indicates partial gene, whereas a and E symbolize respectively successful gene amplification on $C$. canephora cDNA libraries and strong identities with $C$. canephora coffee ESTs.

in our lab [15]. On the 19 remaining coding genes, 16 contain known protein domains in pfam database [18] (Table 1). Among them, a gene coding for an ERF/AP2 transcription factor has been identified from 75,661 to 76,365 bp (g12, CcERF1).

Finally, an unequal distribution of genes was observed along the BAC sequence. The identified genes were distributed in two main locations (from 1 to 76,365 bp and from 119,888 to $160,243 \mathrm{bp}$, Figure 2) with respectively twelve $(\mathrm{g} 1-\mathrm{g} 12)$ and seven genes $(\mathrm{g} 14-\mathrm{g} 20)$ in the $5^{\prime}$ proximal and 3' distal parts of the BAC. The g1-g12 group of gene covers $\sim 76 \mathrm{~kb}$ with a gene density of approximately one gene per $6.3 \mathrm{~kb}$ whereas the g14-g20 group covers a distance of $40.5 \mathrm{~kb}$ with a gene density of one gene per $5.7 \mathrm{~kb}$. The central part of the $\mathrm{BAC}$, containing only one gene ( $g 13)$, covers a distance of $43 \mathrm{~kb}$ (Figure 2 ).

\section{Repeated sequences}

Simple sequence repeats (SSRs)

The availability of the first $C$. canephora BAC sequence allowed us to identify the SSR density in genomic sequences. There were 39 SSRs along the 160,404 bp of the BAC 46C02, giving an overall genomic SSR density of one SSR every $4.1 \mathrm{~kb}$. Most of them (32 SSRs) were simple repeat motifs. The remaining SSRs were di-nucleotides $[\mathrm{CT}]_{20},[\mathrm{CT}]_{9},[\mathrm{TC}]_{9},[\mathrm{AT}]_{9}$ and $[\mathrm{TA}]_{18}$ and tri-nucleotidesmotifs $[\mathrm{GAA}]_{6}$ and $[\mathrm{ATG}]_{7}$. One of the di-nucleotides SSRs $[\mathrm{TC}]_{9}$, called BAC-37, found in the fourth intron of the gene g16, coding for a putative Glycosyl transferase, was mapped on the same linkage group $\mathrm{H}$ of the $[(C$. canephora $\times C$. heterocaly $x) \times C$. canephora $]$ genetic map as the EIN4 marker (Figure 1A and 2). The two markers were $1.4 \mathrm{cM}$ apart. 
Table I: List of identified genes in the C. canephora BAC 46C02.

\begin{tabular}{|c|c|c|c|c|c|}
\hline Gene Name & Product & Protein domain & $\begin{array}{l}\text { Best BLASTN } \\
\text { homology }\end{array}$ & $\begin{array}{l}\text { Best BLASTX } \\
\text { homology }\end{array}$ & $\begin{array}{l}\text { Best BLASTN EST } \\
\text { homology }\end{array}$ \\
\hline $46 \mathrm{CO} 2 \_\mathrm{g} / \mathrm{pb}$ & Putative protein & $\begin{array}{l}\text { pfam0 I843, DIL, DIL } \\
\text { domain }\end{array}$ & $\begin{array}{l}\text { NM_00I064205 O. } \\
\text { sativa (le-I48) }\end{array}$ & $\begin{array}{c}\text { CAO70643 unnamed } \\
\text { protein product } V \text {. vinifera } \\
(3 \mathrm{e}-1 \mid 9)\end{array}$ & AJ796769 A. majus (0.0) \\
\hline $46 \mathrm{CO} 2 \mathrm{~g} 2$ & Expressed Protein & $\begin{array}{l}\text { pfam05764, YLI nuclear } \\
\text { protein }\end{array}$ & $\begin{array}{c}\text { NM_I } 29229 \text { A. thaliana } \\
(5 \mathrm{e}-80)\end{array}$ & $\begin{array}{l}N_{-}|8| 2 \mid 2 \text { DNA binding } \\
\text { A. thaliana (le-90) }\end{array}$ & $\begin{array}{c}\text { DV701332 C. } \\
\text { canephora } \\
\text { (0.0; } 99 \% \text { id.) }\end{array}$ \\
\hline $46 C 02 \_g^{a}$ & Putative protein & pfam0279I, DDT domain & $\begin{array}{c}\text { NM_I I } 7344 \text { A. thaliana } \\
\text { (9e-83) }\end{array}$ & CAO47883 V. vinifera $(0.0)$ & $\begin{array}{c}\text { DY269367 C. clementina } \\
(9 \mathrm{e}-133)\end{array}$ \\
\hline $46 \mathrm{CO} 2 \mathrm{~g} 4$ & Expressed protein & I & $\begin{array}{c}\text { EFI47735 P. trichocarpa } \\
(2 \mathrm{e}-52)\end{array}$ & $\begin{array}{l}\text { ABL97988 putative c-myc } \\
\text { B. rapa }(4 \mathrm{e}-35)\end{array}$ & $\begin{array}{c}\text { DV692405 C. } \\
\text { canephora } \\
\text { (2e-167; 100\% id.) }\end{array}$ \\
\hline $46 \mathrm{CO} 2$ g5 & Expressed protein & $\begin{array}{l}\text { pfam03479, DUF296, } \\
\text { Domain of unknown } \\
\text { function }\end{array}$ & $\begin{array}{c}\text { AJI } 32349 \text { A. majus } \\
(3 e-96)\end{array}$ & $\begin{array}{c}\text { CAO65023 unnamed } \\
\text { protein product V. vinifera } \\
(4 \mathrm{e}-65)\end{array}$ & $\begin{array}{l}\text { DV692183 C. } \\
\text { canephora } \\
\text { (0.0; } 97 \% \text { id.) }\end{array}$ \\
\hline $46 \mathrm{CO} 2 \mathrm{~g}^{6 \mathrm{c}}$ & CcEIN4 & $\begin{array}{l}\text { cd00I56, REC, Signal } \\
\text { receiver domain }\end{array}$ & $\begin{array}{c}\text { AFI I } 8844 \text { L. esculentum } \\
(0.0)\end{array}$ & $\begin{array}{l}\text { AFI I } 8844 \text { ethylene } \\
\text { receptor L. esculentum }(0.0)\end{array}$ & $\begin{array}{c}\text { CK272769 S. tuberosum } \\
(0.0)\end{array}$ \\
\hline $46 C 02 \_g^{a}$ & Expressed protein & $\begin{array}{c}\text { pfam08242, } \\
\text { Methyltransferase domain }\end{array}$ & $\begin{array}{c}\text { BT0I } 4095 \text { L. esculentum } \\
(8 \mathrm{e}-64)\end{array}$ & $\begin{array}{c}\text { CAO65026 unnamed } \\
\text { protein product } V \text {. vinifera } \\
(2 \mathrm{e}-1 \mid 3)\end{array}$ & $\begin{array}{l}\text { DV685577 C. } \\
\text { canephora } \\
\text { (0.0; } 99 \% \text { id.) }\end{array}$ \\
\hline 46C02_g8a & Putative protein & $\begin{array}{l}\text { pfam03479, DUF296, } \\
\text { Domain of unknown } \\
\text { function }\end{array}$ & $\begin{array}{l}\text { AM463589 V. vinifera } \\
(3 \mathrm{E}-158)\end{array}$ & $\begin{array}{c}\text { CAO65027 unnamed } \\
\text { protein product V. vinifera } \\
(8 \mathrm{e}-83)\end{array}$ & $\begin{array}{l}\text { EB084622 C. annuum } \\
\qquad(3 \mathrm{e}-150)\end{array}$ \\
\hline $46 C 02 \_g 9 a$ & Putative protein & 1 & $\begin{array}{c}\text { NM_I I I } 327 \text { A. thaliana } \\
(7 \mathrm{e}-123)\end{array}$ & $\begin{array}{c}\text { CAO65029 unnamed } \\
\text { protein product } V \text {. vinifera } \\
(5 \mathrm{e}-122)\end{array}$ & $\begin{array}{c}\text { BI925858 S. lycopersicum } \\
\text { (3e-I I 4) }\end{array}$ \\
\hline $46 C 02 \_g 10^{a}$ & Putative protein & $\begin{array}{c}\text { cd01926, } \\
\text { cyclophilin_ABH_like }\end{array}$ & $\begin{array}{c}\text { AK24644I S. } \\
\text { lycopersicum (2E-I I 2) }\end{array}$ & $\begin{array}{l}\text { CAN6I038 hypothetical } \\
\text { protein V. vinifera (7e-70) }\end{array}$ & $\begin{array}{l}\text { N980378 S. chacoense } \\
(\text { ( e-I | } 4)\end{array}$ \\
\hline $46 \mathrm{CO} 2 \mathrm{gll}^{\mathrm{a}}$ & Putative protein & 1 & $\begin{array}{l}\text { AM44887I V. vinifera } \\
(5 \mathrm{E}-75)\end{array}$ & $\begin{array}{c}\text { CAO65032 unnamed } \\
\text { protein product } V \text {. vinifera } \\
(|\mathrm{e}-| \mid \mathrm{I})\end{array}$ & $\begin{array}{c}\text { CK272594 S. tuberosum } \\
(2 \mathrm{e}-79)\end{array}$ \\
\hline $46 \mathrm{CO} 2 \mathrm{gl}^{\mathrm{b}}$ & CCERFI & $\begin{array}{l}\text { smart00380, AP2 DNA- } \\
\text { binding domain }\end{array}$ & $\begin{array}{l}\text { AM44I538 V. vinifera } \\
\text { (7E-38) }\end{array}$ & $\begin{array}{c}\text { CAO65033 unnamed } \\
\text { protein product V. vinifera } \\
(3 e-53)\end{array}$ & $\begin{array}{c}\text { CV262586 P. trichocarpa } \\
\text { (3e-36) }\end{array}$ \\
\hline $46 \mathrm{C0} 2 \mathrm{gl}^{\mathrm{a}}$ & Putative protein & $\begin{array}{l}\text { pfam00082, Peptidase_S8; } \\
\text { cd02 I 20, subtilisin_like }\end{array}$ & $\begin{array}{c}\text { AP009276 S. } \\
\text { lycopersicum (8e-170) }\end{array}$ & $\begin{array}{l}\text { CAA064I4 P69F protein S. } \\
\text { lycopersicum }(0.0)\end{array}$ & $\begin{array}{c}\text { CK269227 S. tuberosum } \\
(5 \mathrm{e}-108)\end{array}$ \\
\hline $46 C 02 \_g 14$ & Expressed protein & $\begin{array}{l}\text { smart00I56, PP2Ac, } \\
\text { Protein phosphatase } 2 \mathrm{~A}\end{array}$ & $\begin{array}{c}\text { AJ002485 M. sativa } \\
(0.0)\end{array}$ & $\begin{array}{c}\text { BAF3II } 32 \text { subunit of } \\
\text { protein phosphatase I } \mathrm{V} \\
\text { faba }(2 \mathrm{e}-168)\end{array}$ & $\begin{array}{l}\text { DV705485 C. } \\
\text { canephora } \\
\text { (0.0; 100\% id.) }\end{array}$ \\
\hline $46 C 02 \_g 15$ & Expressed protein & $\begin{array}{l}\text { cd00I80, Serine/ } \\
\text { Threonine protein kinase }\end{array}$ & $\begin{array}{l}\text { AF453448 S. tuberosum } \\
(\text { le-16I) }\end{array}$ & $\begin{array}{c}\text { AF20348I carboxylase } \\
\text { kinase } L \text {. esculentum } \\
(2 \mathrm{e}-126)\end{array}$ & $\begin{array}{l}\text { DV693205 C. } \\
\text { canephora } \\
\text { (0.0; } 99 \% \text { id.) }\end{array}$ \\
\hline $46 C 02 \_g 16$ & Expressed protein & $\begin{array}{l}\text { pfam0I50I, Glycosyl } \\
\text { transferase family } 8\end{array}$ & $\begin{array}{c}\text { BT0I3608 L. esculentum } \\
(0.0)\end{array}$ & $\begin{array}{c}\text { CAO65058 unnamed } \\
\text { protein product } V \text {. vinifera } \\
(0.0)\end{array}$ & $\begin{array}{l}\text { DV705 I } 48 \text { C. } \\
\text { canephora } \\
\text { (0.0; } 99 \% \text { id.) }\end{array}$ \\
\hline $46 C 02 \_g / 7^{b}$ & Putative protein & $\begin{array}{c}\text { pfam00067, Cytochrome } \\
\text { P450 }\end{array}$ & $\begin{array}{c}\text { CUI0469I S. } \\
\text { lycopersicum (2e-30) }\end{array}$ & $\begin{array}{c}\text { CAO66223 unnamed } \\
\text { protein product V. vinifera } \\
(2 \mathrm{e}-109)\end{array}$ & $\begin{array}{c}\text { CF5I3973 V. vinifera } \\
\text { (le-37) }\end{array}$ \\
\hline $46 C 02 \_g 18$ & Putative protein & $\begin{array}{l}\text { pfam07859, } \\
\text { Abhydrolase_3 }\end{array}$ & $\begin{array}{c}\text { AC209222.I P. } \\
\text { trichocarpa (I e-23) }\end{array}$ & $\begin{array}{c}\text { CAO47785 unnamed } \\
\text { protein product V. vinifera } \\
(\text { le-46) }\end{array}$ & $\begin{array}{l}\text { DV677672 C. canephora } \\
\text { (8e-94; } 80 \% \text { id.) }\end{array}$ \\
\hline $46 C 02 \_g 19$ & Putative protein & $\begin{array}{c}\text { cd00I67 DNA-binding } \\
\text { domains }\end{array}$ & $\begin{array}{l}\text { EUI8|424 V. vinifera } \\
(6 \mathrm{e}-84)\end{array}$ & $\begin{array}{c}\text { AAB4IIIOI transcription } \\
\text { factor MybI N. tabacum } \\
(7 \mathrm{e}-60)\end{array}$ & $\begin{array}{l}\text { FC069I64 V. vinifera } \\
\qquad(5 \mathrm{e}-84)\end{array}$ \\
\hline $46 \mathrm{CO} 2 \_\mathrm{g} 20^{\mathrm{b}}$ & Putative protein & Pfam00190, Cupin_I & $\begin{array}{c}\text { X82463 M. salicifolia } \\
(9 \mathrm{e}-27)\end{array}$ & $\begin{array}{c}\text { CAA57846 M. salicifolia } \\
\text { (4e-82) }\end{array}$ & $\begin{array}{c}\text { EE9862 I3 N. nucifera } \\
(\text { le-23) }\end{array}$ \\
\hline 46C02_g2I & tRNA Arg & I & $\begin{array}{c}\text { CUI0469I S. } \\
\text { lycopersicum (9e-29) }\end{array}$ & I & $\begin{array}{c}\text { EX530859 M. truncatula } \\
(5 e-25)\end{array}$ \\
\hline
\end{tabular}

adetected by cDNA amplification, b not detected by cDNA amplification, P Partial gene, c Bustamante-Porras et al., 2006 
Transposable elements (TEs)

In addition to Simple Sequence Repeats, transposable elements (TE) were identified. In total 23 TEs were annotated, accounting for $7.4 \mathrm{~kb}$ of sequence and representing $4.6 \%$ of the BAC sequence (Table 2). The TE density reached one element per $6.97 \mathrm{~kb}$. Transposable elements appeared uniformly distributed along the BAC sequence and no particular accumulation was observed. Only one putative element, weakly similar to the 3' part of a nonLTR retrotransposon in Arabidopsis (AAB82639), falls into the class I retrotransposon group. However, this element appears truncated and highly degenerated. Most annotated TEs belong to the class II transposon group. These identified elements are divided into non-autonomous transposons (five elements), and MITEs (Miniature inverted repeat transposable elements, 17 elements) representing respectively $21.7 \%$ and $73.9 \%$ of all identified elements in the BAC clone. One MITE, called Alex-1 was found nested within the 13th intron of an expressed gene encoding a putative protein ( $g 3$, position $12,468-12,645$ bp, Figure 2).
Similarity searches, using newly identified TEs as query, against publicly available $C$. ESTs and genomic sequences (to date 57,198 and 6,232 sequences, respectively from $C$. canephora and C. arabica) were conducted by BLAST with an E-value cutoff of $10 \mathrm{e}-5$. Similarities were found for most of the identified elements (Table 2). Interestingly, two MITE families called Alex and Gerard were found as the most abundant in each sequence database, suggesting that these two elements belong to large copy number families in the C. canephora genome.

\section{Identifications of homologous regions between $\mathbf{C}$. canephora BAC sequence and reference dicotyledonous genomes}

Microcollinearity studies were conducted between the $C$. canephora BAC and the genomic sequences of five reference plants (tomato, grapevine, barrel medic, black cottonwood and Arabidopsis) belonging to Asterid and Rosid clades. Comparisons were achieved with completely and partially sequenced genomes.

Table 2: List of identified putative transposable elements in the C. canephora BAC 46C02.

\begin{tabular}{|c|c|c|c|c|c|c|}
\hline Class & Repeat Type & group & Number & Name & $\begin{array}{c}\text { Coffea EST BLAST } \\
\text { hits }(>10 \mathrm{e}-5)\end{array}$ & $\begin{array}{c}\text { Coffea genomic } \\
\text { sequence BLAST hits } \\
(>10 \mathrm{e}-5)\end{array}$ \\
\hline I & $\begin{array}{l}\text { Non-LTR } \\
\text { retrotransposon }\end{array}$ & LINE & I & CCRT_Pricilla & 0 & 0 \\
\hline \multirow[t]{22}{*}{ II } & Transposons & $\begin{array}{c}\text { Non-autonomous } \\
\text { transposons }\end{array}$ & 5 & CcTR_Arnaud-I & 0 & 3 \\
\hline & & & & CcTR_Arnaud-2 & 0 & 0 \\
\hline & & & & CcTR_Deless-I & 8 & 21 \\
\hline & & & & CcTR_Deless-2 & 2 & 7 \\
\hline & & & & CcTR_Philippe & 7 & 2 \\
\hline & MITEs & & & CcMT_Alex-I & 40 & 22 \\
\hline & & $!$ & & CcMT_Alex-2 & 49 & 25 \\
\hline & & $!$ & & CCMT_Anis-I & 13 & 8 \\
\hline & & $!$ & & CcMT_Anis-2 & 8 & 7 \\
\hline & & $!$ & & CcMT_Anis-3 & II & 8 \\
\hline & & $!$ & & CcMT_Daniel-I & 17 & 6 \\
\hline & & $!$ & & CcMT_Daniel-2 & 8 & 12 \\
\hline & & $!$ & & CcMT_Daniel-3 & 15 & 15 \\
\hline & & $!$ & & CCMT_Gerard-I & 40 & 21 \\
\hline & & $!$ & & CCMT_Gerard-2 & 37 & 14 \\
\hline & & $!$ & & CCMT_Jose-I & I & 8 \\
\hline & & $!$ & & CCMT_Jose-2 & 4 & 7 \\
\hline & & $!$ & & CcMT_Jose-3 & 0 & 0 \\
\hline & & $!$ & & CcMT_Jose-4 & 0 & 1 \\
\hline & & $!$ & & CcMT_Richard & I & 0 \\
\hline & & $!$ & & CcMT_Serge & I & 9 \\
\hline & & $!$ & & CcMT_Stephane & I & 0 \\
\hline Total & & & 23 & & & \\
\hline
\end{tabular}


The C. canephora BAC shows a partial conservation with a single BAC clone (Le_HBa0008H22 CU104691) located on the chromosome IV of tomato (S. lycopersicum, Solanaceae). Four C. canephora distal genes $(g 15, g 16, g 17$ and $\mathrm{g} 21$ ), separated by an interval of $28 \mathrm{~kb}$, were conserved in the same order and orientation in tomato on a distance of $24 \mathrm{~kb}(51,150-75,409 \mathrm{bp})$, giving a percentage of collinearity of $32 \%$. In this interval, three $C$. canephora contiguous genes $(g 18, g 19$ and $g 20)$ were not found neither in the tomato counterpart nor in any other sequenced tomato BAC clones. Similarly, the other $C$. canephora genes were not found conserved in all released tomato BAC sequences (Figure 3).

The recently released grapevine genome (Vitis vinifera, Vitaceae [19]) allowed us to identify an additional conserved region with the $C$. canephora BAC sequence. In total nine C. canephora predicted genes $(g 4, g 5, C c E I N 4, g 7, g 8$, $g 9, g 10, g 11$ and CcERF1) were strictly conserved in the same order and orientation with the unmapped Scaffold127 of about 1,150 kb length (Le Cunff, L. and Adam-Blondon A.F., personal communication), representing a high percentage of collinearity (56\%). Homologous grapevine genes spread on a large distance of 269.3 $\mathrm{kb}(675-945 \mathrm{~kb})$, which represents an expansion of a factor 4.9 compared to the homologous counterpart in $C$. canephora. The increase of distances is primarily due to expansion of intergenic regions. Close examination and fine annotation of the grapevine $249 \mathrm{~kb}$ segment reveal the presence of numerous transposable elements in intergenic regions such as LTR retrotransposons and transposons (data not shown). Based on the identification of specific coding regions, the annotation showed the presence of nine complete and large size transposable elements. They account together for approximately $50 \mathrm{~kb}$ of sequence, indicating that the expansion of distance rela-

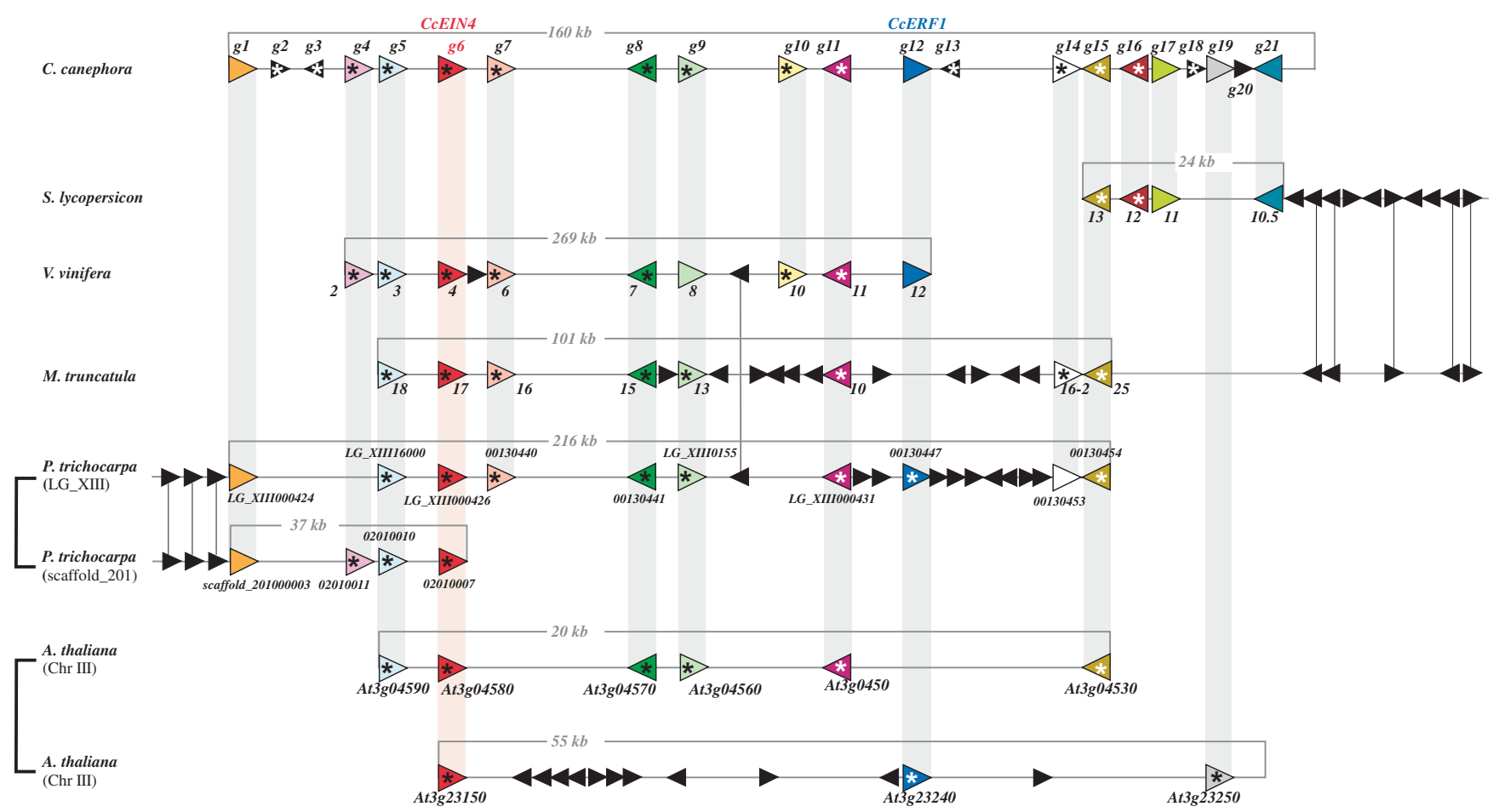

\section{Figure 3}

Overview of the microcollinearity between $C$. canephora 46C02 BAC and genomic regions in Arabidospsis (Arabidopsis thaliana), tomato (S. lycopersicon), Medigago (Medicago truncatula), grapevine (V. vinifera) and black cottonwood (Populus trichocarpa) genomes. Colored arrows with names indicate orientation of predicted coding regions. Stars indicate transcribed genes as suggested by strong EST similarities (see Additional file I). Colored lines link putative orthologous genes between collinear regions and distances between the most distant collinear genes with $C$. canephora $\mathrm{BAC}$ are indicated in each conserved fragment. Black arrows indicate non-conserved predicted genes. S. lycopersicon is a fragment $(5 \mathrm{I}-75 \mathrm{~kb})$ of the Le_HBa0008H22 BAC clone located on chromosome 4. V. vinifera is a part of the scaffold I 27 of I,I50 $\mathrm{kb}$ long.Medicago truncatula indicates a fragment covered by two BAC clones (ACI4686I, ACI73834). Populus trichocarpa corresponds to two fragments located in the linkage group XIII $(3,073-3,289 \mathrm{~kb})$ and in the unlinked scaffold $20 \mathrm{I}$ and Arabidopsis thaliana to two conserved fragments on chromosome III (A: I,22I-I,24I kb and B: 8,255-8,3 I0 kb). Brackets link identify intragenomic duplicated regions. The fragment sizes are not to scale. 
tive to the $C$. canephora segment may be due to a local accumulation of mobile elements in the grapevine counterpart.

The CcEIN4 region shows a strong microcollinearity relationship with two overlapping barrel medic (M. truncatula; Fabaceae) BAC clones (AC146861 and AC173834) on chromosome 1 (Figure 3 ). In total, eight pairs of coding regions $(g 5, C c E I N 4, g 7, g 8, g 9, g 11, g 14$ and $g 15)$ were found in the same order and orientation between scaffold 201 and Medicago, representing a percentage of collinearity of $40 \%$. The Medicago conserved region spans $101 \mathrm{~kb}$ representing a limited contraction compared to the $C$. canephora conserved interval (107 kb), despite the identification of ten extra predicted genes in the Medicago interval compared to $C$. canephora. To date, the other $C$. canephora genes were not found by BLAST searches in Medicago sequences.

Comparisons between the C. canephora BAC and the complete black cottonwood genome ( $P$. trichocarpa, Salicaceae) revealed extensive conservations with two different genomic fragments in populus, within a complex network of microcollinearity. Ten $C$. canephora coding regions $(g 1, g 5, C c E I N 4, g 7, g 8, g 9, g 11, C c E R F 1, g 14$ and g15) were first found in the same order and orientation with a fragment of $215.9 \mathrm{~kb}$ on chromosome XIII (positions on chr. XIII, 3,073-3,289 kb). In addition, four $C$. canephora coding regions $(g 1, g 4, g 5$ and CcEIN4) were also conserved with a $37 \mathrm{~kb}$ part of the unanchored scaffold 201 (111-148 kb) (Figure 3). The percentage of collinearity is $49 \%$ and $32 \%$ for respectively the segment on chromosome XIII and the scaffold 201. Comparisons between C. canephora and black cottonwood homologous segments indicate a limited expansion of distance in black cottonwood compared to C. canephora of a factor 1,6 and 1 in chromosome XIII and scaffold 201 segments respectively (Figure 3).

Finally, comparisons between $C$. canephora and the A. thaliana (Brassicaceae) genome reveal a complex network of microcollinearity with two distinct regions located in the Arabidopsis chromosome III (Figure 3). Homologs of six C. canephora genes ( 85, CcEIN4, g8, g9, g11 and g15) were conserved in the same order and orientation (collinearity of $44 \%$ ) with a fragment $20 \mathrm{~kb}$ long on Arabidopsis Chromosome III at the position 1,221-1,241 kb. Here, four genes $(g 7, g 10, C c E R F 1$ and $g 13)$ on the $C$. canephora interval were not found conserved within the Arabidopsis homologous fragment. In C. canephora, conserved genes were separated by a distance of $107 \mathrm{~kb}$, indicating an expansion of the fragment length by a factor 5.3 compared to Arabidopsis (Figure 3). Furthermore, three additional C. canephora genes (CcEIN4, CcERF1 and g19) were found conserved with an extra part of the Arabidop- sis chromosome III. Here in the $55 \mathrm{~kb}$ of this later fragment (positions on Chr III 8,255-8,310 kb), eleven Arabidopsis genes were not found in the $C$. canephora sequence, that is indicated by the low collinearity percentage $(17 \%)$. Compared to this second Arabidopsis homologous fragment, a $2.2 \times$ expansion of the coffee segment length was observed. Analysis of the two Arabidopsis conserved fragments indicates an ancestral segmental duplicated block involving the two homologous Arabidopsis segments [20-22].

\section{Discussion}

The high gene density in the CcEIN4 region represents a gene-rich segment of the $C$. canephora genome. The organization and composition of the trancriptionally active gene part of the $C$. canephora genome remain unexplored so far. At the CcEIN4 region, the gene density reaches one gene per $7.8 \mathrm{~kb}$. Most of these genes (75\%) were shown to be active or potentially active. This value is similar to the gene density observed in different euchromatic regions in tomato (genome size $950 \mathrm{Mb}$ ), one gene per $6.7 \mathrm{~kb}$ [23] and in the tomato ovate and JOINTLESS loci, one gene per 6.2 and per $8 \mathrm{~kb}$, respectively $[7,24]$. Similarly, the gene density in the C. canephora 46C02 BAC clone is comparable to euchromatic regions in $M$. truncatula (genome size $\sim 500 \mathrm{Mb}$ ), one gene per $6.7 \mathrm{~kb}$ [25] and in rice, one gene per $6.7 \mathrm{~kb}$ [26]. However this density is relatively low compared to the Arabidopsis genome (125 Mb) by a factor $\sim 2$, one gene per $4 \mathrm{~kb},[22,27]$, but still significantly high compared to the Populus genome (genome size 550 $\mathrm{Mb}$ ), one gene per $11.1 \mathrm{~kb},[28]$ and the euchromatic regions in sorghum (genome size $735 \mathrm{Mb}$ ), one gene per $12.3 \mathrm{~kb},[29]$. The C. canephora nuclei have been estimated to contain $\sim 1.43 \mathrm{pg}$ of DNA corresponding to a diploid genome, giving an estimated haploid genome size of $\sim 690$ $\mathrm{Mb}$ [10]. An extrapolation of the gene number identified in the 46C02 BAC clone to the whole C. canephora genome would lead to a predicted gene content of approximately 88,000 genes. This obvious over estimation is significantly higher than the average number of predicted genes in diploid reference plant genomes such as in tomato, 38,000 [30], Arabidopsis, 25,000 [22], grapevine 30,000, Populus, 45,000 [28] and rice, 37,000 [31]. Then, our data suggest that the high density observed at the CcEIN4 region may be not representative of the overall gene density of the $C$. canephora genome but to a high gene density zone. Gene enriched regions were previously identified in dicotyledonous plant genomes such as tomato and Medicago [23,32]. The tomato genome may cluster most of the active genes within $25 \%$ of the $950 \mathrm{Mb}$ genome representing the euchromatin [23]. In Medicago, euchromatin, identified by FISH hybridization with gene-rich BAC clones, represents $20 \%$ of the $500 \mathrm{Mb}$ genome [32]. These gene rich regions in the genomes of tomato and Medicago are currently targets of large-scale 
genome sequencing projects. Because genes are probably not uniformly distributed along $C$. canephora chromosomes, we hypothesize that the high gene density in the CcEIN4 region represents a gene-rich segment in the $C$. canephora genome.

The presence of a high number of identified MITEs in the CcEIN4 region is correlated with the presence of a high gene density. The transposable element composition of the BAC indicates a strong bias in the presence of Class II elements compared to Class I. With the exception of a degenerated part of a non-LTR retrotransposon, all identified elements have short lengths and are considered as non-autonomous because they lack coding capacities for a transposase involved in their mobility [33]. Due to their structural characteristics such as their small size (usually less than $500 \mathrm{bp}$ ), the presence of short Terminal Inverted Repeat (TIR) at both ends and a high A/T content, most of these elements $(73.9 \%)$ were identified in C. canephora as Miniature Inverted-repeat Transposable Elements (MITE), a shorter derivative of non-autonomous class II DNA transposons [34,35]. MITE families were shown to be the most abundant TEs in plant genomes, with probably more than 90,000 copies in the rice genome [36]. Particularly, MITEs were frequently found associated with coding regions in plant genomic sequence with insertion into introns as well as into untranslated and promoter regions $[24,37,38]$, which was confirmed with the complete sequencing of the Arabidopsis and rice genomes. Here, the identified MITEs were closely associated with coding regions as demonstrated by their distribution on the $C$. canephora BAC and their redundancies in C. canephora EST sequences.

The CcEIN4 region is located in the euchromatic part of the $C$. canephora. Although the organization of gene-rich regions along $C$. canephora chromosomes remains unknown, previous cytological observations in $C$. canephora and $C$. arabica chromosomes have clearly shown a pattern of deeply and lightly staining regions indicating an overall chromosome organization in respectively condensed heterochromatin and decondensed euchromatin regions $[39,40]$. Similarly to Medicago and tomato chromosome architecture, C. canephora heterochromatin regions are mainly located around centromeric regions while euchromatin constitutes the distal parts of chromosomes [13,32].

Based on these cytological observations and the similar composition observed between euchromatic regions in tomato, in Medicago and the sequenced BAC clone $46 \mathrm{C} 02$, we suggest that the CcEIN4 region is located in the euchromatic part of the $C$. canephora chromosome corresponding to the LG H of C. heterocalyx.
Comparison of the gene order between a $C$. canephora $\mathrm{BAC}$ clone and reference dicotyledonous genome sequences shows extensive conservation. Comparative genomic studies are essential approaches to understand the evolution of genome structure and to investigate the conservation of gene order between closely and distantly related plant species. The evaluation of the genome conservation allows the transfer of information from model species as references to "orphan" genomes lacking the availability of resources and may enhance the identification of gene of interest through map-based cloning strategies [41]. The sequencing of a gene rich region in $C$. canephora and the availability of several complete or forthcoming sequenced model dicotyledonous genomes such as Arabidopsis, black cottonwood, barrel medic, tomato and grape allowed us to investigate multiple microcollinearity relationships over distantly related species covering two different clades: Asterids and Rosids.

The CcEIN4 region is clearly microcollinear with one homologous region in tomato, grapevine and Medicago and two homologous regions in Arabidopsis and in Populus genomes. Phylogenetically, C. canephora is closely related to tomato since they belong to the Asterid I clade and diverged from a common ancestor about 83-89 Million Years Ago (MYA) (Figure 4)[42]. Arabidopsis, Medicago, Populus and grapevine are more distant than tomato since they are all members of the Rosid clade, which diverged from the Asterid one 114-125 MYA (Figure 4). In the region studied here the number of collinear segments per genome and the degree of microcollinearity appeared heterogeneous. The CcEIN4 region is microcollinear with one homologous region both in tomato, grapevine and Medicago chromosomes, but scattered on two regions in Arabidopsis and in Populus genomes with a different degree of collinearity for each pair of homologous segments. These extra microcollinear segments lead

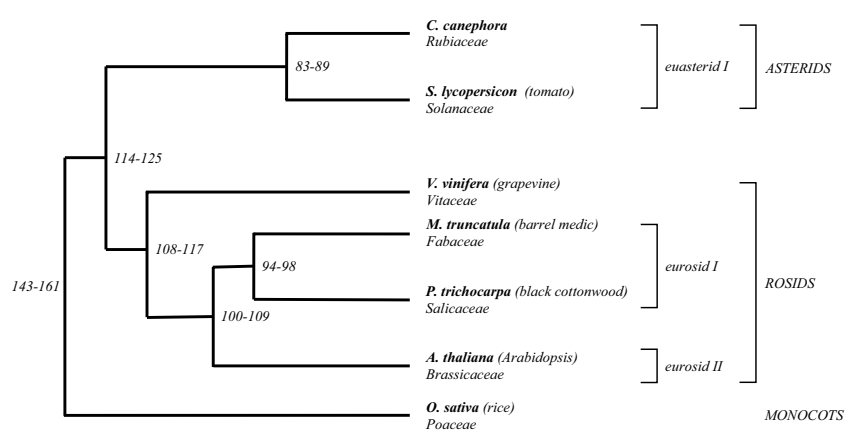

Figure 4

Dendogram representing the phylogenetic relationships between $C$. canephora and reference eudicotyledonous genomes. The time-scale of the divergence of the angiosperm families are indicated as published in Wilkstrom et al., [42]. 
to a complex network of conservation similar to that observed between tomato and Arabidopsis [6,7], Medicago and Arabidopsis [4,5], Medicago, soybean and Arabidopsis [43], Populus and Cucumis [9] and Arabidopsis and legumes genomes [5]. Such a network of conservation was recently suggested at synteny level between markers of the C. arabica $\mathrm{S}_{\mathrm{H}} 3$ region and Arabidopsis chromosomes $1,3,4$ and 5 [44]. The analysis of networks of collinearity contributed to the discovery of recent large-scale chromosome duplications that shaped the genomes of Arabidopsis, Populus and Medicago, as well as the understanding of the evolutionary mechanisms that reorganized the duplicated blocks $[20,21,28,45]$. Moreover, recent comparative analysis between grapevine and the different reference genomes such as Arabidopsis, Populus and rice suggested no recent duplication, but an ancestral contribution of three genomes in grapevine common to all Eurosid plants [19], The data reported here confirm the paleopolyploid structure of the Arabidopsis and the Populus genomes. However, few collinear genes were found conserved between paralogous segments in Arabidopis and Populus, corresponding to the C. canephora CcEIN4 region. In Arabidopsis an extensive process of selective gene loss has shaped the paralogous segments while in Populus the duplicated block appeared very limited in length. Similar observations were described in other regions of paleopolyploid plant genomes where duplicated blocks were found subjected to intense mechanisms of gene movements and large rearrangements [20,28]. Although the presence of genome duplications and ancient triplication were respectively established in Medicago and suggested in grapevine, no network of collinearity was found between the C. canephora CcEIN4 region and these model species. Similar observations were found between the melon linkage group 11 and Medicago sequences [9] and between chickpea and Medicago sequences [46] reflecting the incomplete sequence of the Medicago genome or a region not covered by ancient polyploidization events in the Medicago and the grapevine genomes.

Considering the divergence between $C$. canephora and the model dicotyledonous plant genomes studied in this work, we expected a higher degree of microcollinearity between the Rubiaceae and the Solanaceae families than between Asterid and the distantly related Rosid clades. Synteny was observed between tomato and C. canephora in preliminary comparative mapping using COSII markers and microcollinearity relationships were previously demonstrated between tomato and the distant species Arabidopsis $[6,7,24]$. However, in the present work, only four genes were conserved in the same order and orientation over a similar distance and homologs of other Coffea genes were not present in all currently released tomato BAC sequences. Unfortunately, to date no tomato BAC sequence overlapping the entire homologous $C$. canephora BAC sequence is publicly available, suggesting that the homologous CcEIN4 region was not completely sequenced as part of the tomato genome project. Progress in the tomato sequencing project and future large scale genomic sequencing in $C$. canephora will allow us to reevaluate the microcollinearity over several regions and to determine the limits of tomato genome as a tool to identify candidate genes in C. canephora. Nine genes were found strictly collinear and only two coding regions, located in the grapevine interval, were absent in the $C$. canephora counterpart. In contrast, an unexpected degree of microcollinearity was found between $C$. canephora and all Rosid plant genomes used in this study. The higher degree of microcollinearity (56\%) corresponds to the comparisons between $C$. canephora and grapevine regions. In this later case, nine genes were found strictly collinear and only two coding regions, located in the grapevine interval, were absent in the $C$. canephora counterpart. Despite the high degree of microcollinearity, an expansion of distance of a factor 4.9 in grapevine was observed due to differential accumulations of transposable elements in intergenic spaces. This expansion of distance in grapevine is not correlated with the genome sizes in grapevine ( $504 \mathrm{Mb},[47])$ and in C. canephora ( $690 \mathrm{Mb}$, [10]).

As it was previously observed in comparative analysis in grass genomes, massive insertions and deletions of TEs may promote a rapid genome evolution and may participate in the disruption of the microcollinearity [48]. Our analyses suggest that beside the alteration of distance, insertions of TE in grapevine show no impact on microcollinearity. Our observations indicate that a significant microcollinearity may be expected between $C$. canephora and grapevine. Phylogenetically, grapevine belongs to the Vitaceae family that is the earliest diverging lineage of the Rosid clade [49]. To date, it remains unclear whether the phylogenetic relationships of Vitaceae are at the origin of the local genome conservation with $C$. canephora.

The level of microcollinearity is still fairly high with Populus (LG XIII, 49\%), Arabidopsis (segment A, 40\%) and Medicago segments (40\%) but lower than with grapevine. Several disruptions of the microcollinearity were observed between C. canephora and Populus, Arabidopsis and Medicago giving a mosaic pattern of conservation. In Populus and Medicago, the disruptions of the microcollinearity are due to the presence of numerous nonconserved genes with the $C$. canephora counterpart. Most of the extra genes in Populus and Medicago are not collinear across the Rosid model species suggesting that these gene insertions may arise from independent events of gene translocation mechanisms. Five genes located downstream the collinear region between Medicago and C. canephora were found to 
be collinear between Medicago and tomato. The extension of the microcollinearity pinpoints the complete absence in Medicago of a cluster of six genes present in $C$. canephora ( $g 16$ to g21), reinforcing the mosaic pattern of the gene conservation.

Despite the observation of the microcollinearity disruption, and considering the large number of collinear genes and distantly related species involved in this analysis, we conclude that the C. canephora CcEIN4 region is significantly conserved with all reference dicotyledonous species used in our analysis. Such observations raise the question whether the microcollinearity observed at the CcEIN4 region can be representative of the conservation between distantly related species or indicative of a larger conservation of the genome organization. So far, no other comparative analysis has been performed between C. canephora or any other Rubiaceae genomic sequences, and model dicotyledonous plant species. Further comparative mapping across dicotyledonous species will provide useful information about the conservation of the plant genome structure and also to determine a set of model genomes to infer positional information of candidate genes in $C$. canephora.

\section{Conclusion}

In conclusion, our exploration of the first sequenced BAC clone in the Rubiaceaae family represents the first step in the understanding the $C$. canephora genome composition, structure, and evolution. Particularly C. canephora shows a remarkable level of microcollinearity with the distantly related Rosid species. In the absence of the complete tomato genome sequence, our data suggest the grapevine genome may be useful to obtain information to identify candidate genes in C. canephora.

\section{Methods}

\section{Screening C. canephora BAC library and manipulation of BAC DNA}

The screening of the C. canephora (clone IF 126) BAC library [12] representing approximately 9 genome equivalents was carried out using specific probe located in the previously isolated CcEIN4 gene [15]. The probe was amplified from the CcEIN4 cDNA with the following specific primers: SEIN4F 5'-GCCCTTGCGATTAATGAACCAG-3' and SEIN4R AGGCACAAGCACTTAACCAAACAA-3'. Probe preparation and BAC library high-density filters hybridization were performed as described in [16]. Through the hybridization, the BAC 46C02 was selected for further analysis. DNA of BAC 46C02 was isolated using the Plasmid Midi Kit (Qiagen Courtaboeuf, France) and used for further analyses. The insert size estimation was carried out by pulsed field (BioRad CHEF Gel Apparatus) with BAC
DNA digested by NotI with the following parameters: volts $/ \mathrm{cm}=5.0$; included angle $120^{\circ}$; run time $=15$ hours at $14^{\circ} \mathrm{C}$; initial switch time $=5 \mathrm{sec}$; final switch time $=15$ sec.

\section{BAC-FISH mapping}

The 46C02 BAC clone was labeled by random priming with biotin-14-dUTP (Invitrogen, Cergy-Pontoise, France). The ribosomal probe used in this study was pTa 71 [50] which contained a 9-kb EcoRI fragment of rDNA repeat unit (18S-5.8S-26S genes and spacers) isolated from Triticum aestivum. pTa 71 was labelled with Alexa488 dUTP by random priming (Fisher Bioblock Scientific, Illkirch, France).

Chromosome preparations from C. canephora (genotype BB62, from Central African Republic) were incubated in Rnase A $(100 \mathrm{ng} / \mu \mathrm{L})$ and pepsin $(0.05 \%)$ in $10 \mathrm{mmol}$ HCL, fixed with paraformaldehyde $(1 \%)$, dehydrated in an ethanol series $(70 \%, 90 \%$ and $100 \%)$ and air-dried. The hybridization mixture consisted of $50 \%$ deionized formamide, $10 \%$ dextran sulfate, $2 \times$ SSC, $1 \%$ SDS and labelled probes (200 ng per slide), was denatured at $92^{\circ} \mathrm{C}$ for $6 \mathrm{~min}$, and transferred to ice. Chromosomes were denatured in a solution of $70 \%$ formamide in $2 \times$ SSC at $70^{\circ} \mathrm{C}$ for $2 \mathrm{~min}$. The denatured probe was placed on the slide and in situ hybridization was carried out overnight in a moist chamber at $37^{\circ} \mathrm{C}$. After hybridization, slides were washed for $5 \mathrm{~min}$ in $50 \%$ formamide in $2 \times \mathrm{SSC}$ at $42^{\circ} \mathrm{C}$, followed by several washes in $4 \times$ SSC-Tween. The chromosomes were mounted and counterstained in Vectashield (Vector Laboratories) containing $2.5 \mu \mathrm{g} / \mathrm{mL} \mathrm{4',6-}$ diamidino-2-phenylindole (DAPI). Fluorescence images were captured using a CoolSnap HQ camera (Photometrics, Tucson, Ariz) on an Axioplan 2 microscope (Zeiss, Oberkochen, Germany) and analysed using MetaVue ${ }^{\mathrm{TM}}$ (Universal Imaging Corporation, Downington, PA).

\section{$B A C$ sequencing}

The BAC DNA was first sub-cloned into the TOPO vector (Invitrogen, Cergy Pontoise, France) and 70 sub-clones were randomly selected for low-pass sequencing. Complete sequencing of the BAC 46C02 was performed by MWG Biotech (Ebersberg, Germany). A total of 1105 reads were produced giving an average coverage of $5.4 \times$. After shotgun sequencing, sequences were assembled using the Phred/Phrap software [51], producing an assembly of 13 contigs. Regions of low quality as well as gaps between contigs were filled by PCR amplifications with specific primers and then sequenced (MWG Biotech). The final error rate for the BAC sequence was below 1 base per $10 \mathrm{~kb}$. The BAC sequence was deposited in GenBank under the accession number EU164537. 


\section{Genetic analysis}

Two internal primers in the CcEIN4 gene were first designed (EIN4-RTF: AGAAGCTAGTTGGCATGTCCGGAT EIN4-RTR: GCAACTCGCAGCACCAAGTACTGA) and used as STS (Sequence Tag Site) for genetic mapping. The resulting marker was denominated EIN4. Using the SSR pipeline program [52], a microsatellite repeat [TC] (called BAC-37) was detected in silico at $105 \mathrm{~kb}$ away from the CcEIN4 gene. Flanking primers were designed (BAC37-F: TCATTTTTGTCCGGGGATAC, BAC-37-R: ATGGAAA CCGAAGAGGAAAG), and tested for amplification. PCR amplification was carried out on genomic DNA as described in [53]. Segregation analyses were performed on the interspecific progeny (74 individuals) derived from the back-cross $[(C$. canephora $\times C$. heterocalyx $) \times C$. canephora], which had been used to build a genetic map ([54] and unpublished results). Linkage analyses were performed using MAPMAKER/EXP 3.0b [55,56], and Mapdisto (version 1.37, available via http://map disto.free.fr) software packages.

\section{Sequence Analysis and Gene Annotation Methods}

The final BAC sequence was analyzed using BLAST algorithms [57] against public and local plant nucleotide and protein databases. Coding regions were first $a b$ initio predicted using the FGENESH [58] gene finder software trained for three different eudicot gene species (N. tabacum, S. lycopersicum and $V$. vinifera) since no training set for $C$. canephora was available so far. Evaluation of predicted gene structures (i.e. coding regions, spliced sites, start and stop codons), were manually conducted by alignments with protein and nucleotide genomic sequences and confirmed by local alignments with Coffea public ESTs or specific cDNA PCR amplifications followed by sequencing. An additional genes structure validation was conducted by Felipe Rodrigues da Silva from the Cenergen (Embrapa) on C. arabica ESTs isolated by the Brazilian Coffee Genomic Consortium http:// www.lge.ibi.unicamp.br/cafe/. Predicted genes with no similarity hits in all protein and nucleotide sequence databases were rejected in final annotation and considered as putative inaccurate predictions. Detailed analysis was performed with the EMBOSS Analysis software [59] and the final annotation was performed using Artemis [60].

\section{Annotation and classification of repeated sequences}

Microsatellite (SSR) markers were identified using the SSR pipeline program with previously described parameters [52]. Putative transposable elements (TEs) were first identified and annotated by RepeatMasker http://www.repeat masker.org searches against local databases of nucleotide and protein sequences of known plant TEs. De novo prediction of TEs was performed according to the structure of the different class of TEs such as tandem and inverted repeats using dot-plot alignments, (Dotter software [61]).
Putative TEs were named according to the following nomenclature: the first two letters of each TE name represent the acronym of the species (i.e. Cc for Coffea canephora), the following two letters indicate the type of TE (RT for retrotransposon; TR for transposon; MT for MITE, HL for helitron and UN for unknown class of repeat) and following a hyphen the specific name of the element.

\section{PCR Amplifications on cDNA libraries}

Two C. canephora cDNA libraries, prepared from young leaves and fruits at different stages of development and maturation [62] were used for PCR amplifications with specific primers designed from genes identified on the BAC clone 46C02 (5'-GGCTGAGTTGGAACACTGGT-3' and 5'-TTAGGCTGGAAGCAAGAAGC-3' for 46C02_g1, 5'-GTTTGGTTGCTGGGTCTCAT-3' and 5'-CGACAAGAGGAAAGCCTCAC-3' for 46C02_g3， 5'-ACGAGTGGGTTTCCTGAGTG-3' and 5'-TGGGTCTCTGGAACTTACCG-3' for 46C02_g7, 5'-ACTCGGAGGCCTAGAGGAAG-3' and 5'-TAAAGCCATGACTGCACCAG-3' for 46C02_g8, 5'GCTCTCAAACGTCCAAAACC-3' and 5'-AGCCTTTCCC ACCTCTGTTT-3' 46C02_g9, 5'-GAAAACTTTCG CGCTCTTTG-3' and 5'-CCAGGTTGGATGTGCTTCTT-3' for 46C02_g10, 5' AATACCGCAATCTCGACACC-3' and 5'-ACGCAGTCCTATGCTCCTGT-3' for 46C02_g11, 5'ATTCCCAGCATTGTCAGTCC-3' and 5'-TGCATCTGCTTCAACGACTC-3' for 46C02_g12, 5'-CTACTGCTTTGCTCGGGAAC-3' and 5'-GGAGCATGATCGTCTCCAAT3' for 46C02_g13, 5'-GATGGAGAAATCCCAAATGC-3' and 5'-GACTGCAGGATGTTCAGCAA-3' for 46C02_g17, 5'-TCAAAAGTTTGAGTCGTTTGGA-3' and 5'-ACCAGCA CTATCCCCACAAA-3' for 46C02_g18, 5'-GCAGGCTCATCTTTGCAAGT-3' and 5'-AAATG GGAA GGTTCA TGCTG-3' for to 46C02_g20). Amplified products were directly sequenced without cloning.

\section{Analysis of the microcollinearity with plant genomes}

To study in detail the microcollinearity relationships between $C$. canephora and model dicotyledonous genomes, the nucleotide and protein sequences of twenty predicted coding genes and one tRNA from the $C$. canephora BAC were used as queries for BLAST searches against a local database composed of A. thaliana, S. lycopersicum, $M$. truncatula, $P$. trichocarpa and $V$. vinifera nucleotide and protein sequences downloaded respectively from TAIR http://www.arabidopsis.org, SOL http:// www.sgn.cornell.edu/, M. truncatula sequencing resources http://www.medicago.org/, JGI http://genome.jgi-psf.org/ Poptr1/Poptr1.home.html and the $V$. vinifera genome database http://www.plantgdb.org/VvGDB/down load.php. Coding regions in non-annotated genomic sequences were identified using FGENESH [58] trained with the appropriate genome matrix. Collinear regions were defined as the conservation of a minimum of three 
genes in a maximum distance of $200 \mathrm{~kb}$ between compared sequences. In order to specify the robustness of the observed collinearity relationships we calculated a percentage of collinearity as the number of genes involved in the collinearity relationships in the two segments, divided by the total number of genes only present in the collinear part of the two segments compared.

\section{Authors' contributions}

RG MdlM CC and JPB carried out the genomics and bioinformatics studies, VV, PH and OC performed FISH experiments, VP conducted the molecular genetic studies, RG and AdK managed the overall project and RG, AdK PH and $\mathrm{SH}$ contributed to the manuscript writing. All authors read and approved the final manuscript.

\section{Additional material}

\section{Additional file 1}

List of homologous collinear predicted genes between C. canephora BAC 46C02 and Arabidospis, tomato, Medicago, grapevine and Populus. The data provided represent all homologous $\mathrm{C}$. canephora genes found by similarity searches and used to study the collinearity between $\mathrm{C}$. canephora and sequenced genomes.

Click here for file

[http://www.biomedcentral.com/content/supplementary/14712229-9-22-S1.pdf]

\section{Acknowledgements}

The authors thank Alan Andrade and Felipe Rodrigues da Silva (Cenargen, Embrapa, Brazil) for their help in coffee gene annotations, Loïc Le Cunff and Anne-Françoise Adam-Blondon for help in searches in Vitis vinifera genomic sequences and the GDR3047 "Cytogénomique Structurale et Evolutive" for support. The authors thank two anonymous reviewers for their valuable comments to improve the manuscript.

\section{References}

I. Bonierbale MW, Plaisted RL, Tanksley SD: RFLP Maps Based on a Common Set of Clones Reveal Modes of Chromosomal Evolution in Potato and Tomato. Genetics 1988, I 20(4): I095-I 103.

2. Paterson $A H$, Bowers JE, Burow MD, Draye $X$, Elsik $C G$, Jiang $C X$, Katsar CS, Lan TH, Lin YR, Ming R, Wright RJ: Comparative genomics of plant chromosomes. Plant Cell 2000, I 2(9): 1523-1540.

3. Gale MD, Devos KM: Comparative genetics in the grasses. Proc Natl Acad Sci USA 1998, 95(5): 1971-1974.

4. Zhu H, Kim DJ, Baek JM, Choi HK, Ellis LC, Kuester H, McCombie WR, Peng HM, Cook DR: Syntenic relationships between Medicago truncatula and Arabidopsis reveal extensive divergence of genome organization. Plant Physiol 2003, I3 I(3): $1018-1026$.

5. Kevei Z, Seres A, Kereszt A, Kalo P, Kiss P, Toth G, Endre G, Kiss GB: Significant microsynteny with new evolutionary highlights is detected between Arabidopsis and legume model plants despite the lack of macrosynteny. Mol Genet Genomics 2005, 274(6):644-657.

6. Guyot R, Cheng X, Su Y, Cheng Z, Schlagenhauf E, Keller B, Ling HQ: Complex organization and evolution of the tomato pericentromeric region at the FER gene locus. Plant Physiol 2005, I38(3): | 205-| 2 | 5.
7. Ku HM, Vision T, Liu J, Tanksley SD: Comparing sequenced segments of the tomato and Arabidopsis genomes: large-scale duplication followed by selective gene loss creates a network of synteny. Proc Natl Acad Sci USA 2000, 97(16):9121-9126.

8. Rossberg M, Theres K, Acarkan A, Herrero R, Schmitt T, Schumacher K, Schmitz G, Schmidt R: Comparative sequence analysis reveals extensive microcolinearity in the lateral suppressor regions of the tomato, Arabidopsis, and Capsella genomes. Plant Cell 200I, I3(4):979-988.

9. Deleu W, Gonzalez V, Monfort A, Bendahmane A, Puigdomenech P, Arus $P$, Garcia-Mas J: Structure of two melon regions reveals high microsynteny with sequenced plant species. Mol Genet Genomics 2007, 278(6):61 I-622.

10. Noirot M, Poncet V, Barre P, Hamon P, Hamon S, De Kochko A: Genome size variations in diploid African Coffea species. Ann Bot (Lond) 2003, 92(5):709-7I4.

II. Berthaud J: Les ressources génétiques pour l'amélioration des caféiers africains diploïdes. Montpellier, France, ORSTOM, collection Travaux et documents 1986:379.

12. Leroy T, Marraccini P, Dufour M, Montagnon C, Lashermes P, Sabau $X$, Ferreira LP, Jourdan I, Pot D, Andrade AC, Glaszmann JC, Vieira LG, Piffanelli P: Construction and characterization of a Coffea canephora BAC library to study the organization of sucrose biosynthesis genes. Theor Appl Genet 2005, I I I(6): I032-I04 I.

13. Lin C, Mueller LA, Mc Carthy J, Crouzillat D, Petiard V, Tanksley SD: Coffee and tomato share common gene repertoires as revealed by deep sequencing of seed and cherry transcripts. Theor Appl Genet 2005, I I 2(I): I I 4- I 30.

14. Bustamante-Porras J, Noirot M, Campa C, Hamon S, de Kochko A: Isolation and characterization of a novel coffee tree ERF-like cDNA. African J Biotech 2005, 4(2): I57-159.

15. Bustamante J, Poncet V, Campa C, Noirot M, Hamon S, de Kochko A: Characterization of three ethylene receptor genes in Coffea canephora Pierre. Advances in Plant Ethylene Research A Ramina et al Eds Springer 2006:53-56.

16. Bustamante-Porras J, Campa C, Poncet V, Noirot M, Leroy T, Hamon $\mathrm{S}$, de Kochko A: Molecular characterization of an ethylene receptor gene (CcETRI) in coffee trees, its relationship with fruit development and caffeine content. Mol Genet Genomics 2007, 277(6):701-7I2.

17. Tieman DM, Klee HJ: Differential expression of two novel members of the tomato ethylene-receptor family. Plant Physiol 1999, I20(I): I65-172.

18. Bateman A, Coin L, Durbin R, Finn RD, Hollich V, Griffiths-Jones S, Khanna A, Marshall M, Moxon S, Sonnhammer EL, Studholme DJ, Yeats C, Eddy SR: The Pfam protein families database. Nucleic Acids Res 2004:DI38-14I.

19. Jaillon O, Aury JM, Noel B, Policriti A, Clepet C, Casagrande A, Choisne N, Aubourg S, Vitulo N, Jubin C, Vezzi A, Legeai F, Hugueney P, Dasilva C, Horner D, Mica E, Jublot D, Poulain J, Bruyere C, Billault A, Segurens B, Gouyvenoux M, Ugarte E, Cattonaro F, Anthouard V, Vico V, Del Fabbro C, Alaux M, Di Gaspero G, Dumas V, Felice N, Paillard S, Juman I, Moroldo M, Scalabrin S, Canaguier A, Le Clainche I, Malacrida G, Durand E, Pesole G, Laucou V, Chatelet P, Merdinoglu D, Delledonne M, Pezzotti M, Lecharny A, Scarpelli C, Artiguenave F, Pe ME, Valle G, Morgante M, Caboche M, Adam-Blondon AF, Weissenbach J, Quetier F, Wincker $P$ : The grapevine genome sequence suggests ancestral hexaploidization in major angiosperm phyla. Nature 2007, 449(7 I 6 I):463-467.

20. Blanc G, Barakat A, Guyot R, Cooke R, Delseny M: Extensive duplication and reshuffling in the Arabidopsis genome. Plant Cell 2000, I 2(7): 1093-II0I.

21. Blanc G, Hokamp $\mathrm{K}$, Wolfe $\mathrm{KH}$ : A recent polyploidy superimposed on older large-scale duplications in the Arabidopsis genome. Genome Res 2003, I3(2): |37-| 44.

22. AGI: Analysis of the genome sequence of the flowering plant Arabidopsis thaliana. Nature 2000, 408(68 I 4):796-8I5.

23. Wang Y, Tang X, Cheng Z, Mueller L, Giovannoni J, Tanksley SD: Euchromatin and pericentromeric heterochromatin: comparative composition in the tomato genome. Genetics 2006, I 72(4):2529-2540.

24. Mao L, Begum D, Goff SA, Wing RA: Sequence and analysis of the tomato JOINTLESS locus. Plant Physiol 200 I, I 26(3): | 33 | - 340.

25. Young ND, Cannon SB, Sato S, Kim D, Cook DR, Town CD, Roe BA, Tabata S: Sequencing the genespaces of Medicago truncatula and Lotus japonicus. Plant Physiol 2005, I 37(4): I I 74- I I 8 I. 
26. Jiao $Y$, jia $P$, Wang $X$, Su N, Yu S, Zhang D, Ma L, Feng $Q$, jin Z, Li L, Xue $Y$, Cheng Z, Zhao H, Han B, Deng XW: A tiling microarray expression analysis of rice chromosome 4 suggests a chromosome-level regulation of transcription. Plant Cell 2005, 17(6):164|-1657.

27. Copenhaver GP, Nickel K, Kuromori T, Benito MI, Kaul S, Lin X, Bevan M, Murphy G, Harris B, Parnell LD, McCombie WR, Martienssen RA, Marra M, Preuss D: Genetic definition and sequence analysis of Arabidopsis centromeres. Science 1999, 286(5449):2468-2474.

28. Tuskan GA, Difazio S, Jansson S, Bohlmann J, Grigoriev I, Hellsten U, Putnam N, Ralph S, Rombauts S, Salamov A, Schein J, Sterck L, Aerts A, Bhalerao RR, Bhalerao RP, Blaudez D, Boerjan W, Brun A, Brunner A, Busov V, Campbell M, Carlson J, Chalot M, Chapman J, Chen GL, Cooper D, Coutinho PM, Couturier J, Covert S, Cronk Q, Cunningham R, Davis J, Degroeve S, Dejardin A, Depamphilis C, Detter J, Dirks B, Dubchak I, Duplessis S, Ehlting J, Ellis B, Gendler K, Goodstein D, Gribskov M, Grimwood J, Groover A, Gunter L, Hamberger $B$, Heinze B, Helariutta $Y$, Henrissat $B$, Holligan D, Holt R, Huang W, Islam-Faridi N, Jones S, Jones-Rhoades $\mathrm{M}$, Jorgensen R, Joshi C, Kangasjarvi J, Karlsson J, Kelleher C, Kirkpatrick R, Kirst M, Kohler A, Kalluri U, Larimer F, Leebens-Mack J, Leple JC, Locascio P, Lou Y, Lucas S, Martin F, Montanini B, Napoli C, Nelson DR, Nelson C, Nieminen K, Nilsson O, Pereda V, Peter G, Philippe R, Pilate G, Poliakov A, Razumovskaya J, Richardson P, Rinaldi C, Ritland K, Rouze P, Ryaboy D, Schmutz J, Schrader J, Segerman B, Shin H, Siddiqui A, Sterky F, Terry A, Tsai CJ, Uberbacher E, Unneberg P, Vahala J, Wall K, Wessler S, Yang G, Yin T, Douglas C, Marra M, Sandberg G, Peer $Y$ Van de, Rokhsar D: The genome of black cottonwood, Populus trichocarpa (Torr. \& Gray). Science 2006, 313(5793): 1596-I604.

29. Kim JS, Islam-Faridi MN, Klein PE, Stelly DM, Price HJ, Klein RR, Mullet JE: Comprehensive molecular cytogenetic analysis of sorghum genome architecture: distribution of euchromatin, heterochromatin, genes and recombination in comparison to rice. Genetics 2005, I7I(4): I 963-1976.

30. Hoeven R Van der, Ronning C, Giovannoni J, Martin G, Tanksley S: Deductions about the number, organization, and evolution of genes in the tomato genome based on analysis of a large expressed sequence tag collection and selective genomic sequencing. Plant Cell 2002, I4(7): | $44|-| 456$.

31. IRGSP: The map-based sequence of the rice genome. Nature 2005, 436(7052):793-800.

32. Kulikova O, Gualtieri G, Geurts R, Kim DJ, Cook D, Huguet T, de Jong JH, Fransz PF, Bisseling T: Integration of the FISH pachytene and genetic maps of Medicago truncatula. Plant J 200I, 27(I):49-58.

33. Feschotte $\mathrm{C}$, Jiang N, Wessler SR: Plant transposable elements: where genetics meets genomics. Nat Rev Genet 2002, 3(5):329-34I.

34. Wessler SR, Bureau TE, White SE: LTR-retrotransposons and MITEs: important players in the evolution of plant genomes. Curr Opin Genet Dev 1995, 5(6):8|4-82I.

35. Feschotte C, Pritham EJ: DNA transposons and the evolution of eukaryotic genomes. Annu Rev Genet 2007, 41:33I-368.

36. Turcotte K, Srinivasan S, Bureau T: Survey of transposable elements from rice genomic sequences. Plant J 200I, 25(2):169-179.

37. Feschotte C, Wessler SR: Mariner-like transposases are widespread and diverse in flowering plants. Proc Natl Acad Sci USA 2002, 99(I):280-285.

38. Macas J, Neumann P, Pozarkova D: Zaba: a novel miniature transposable element present in genomes of legume plants. Mol Genet Genomics 2003, 269(5):624-63I.

39. Pinto-Maglio CAF, Da Cruz ND: Pachytene chromosome morphology in Coffea L. II. C. arabica L. complement. Caryologia 1998, 5 I (I):19-35.

40. Pinto-Maglio CAF, Da Cruz ND: Pachytene chromosome morphology in Coffea L. I. Nucleolar chromosomes. Caryologia 1987, 40:7-23.

4I. Ku HM, Liu J, Doganlar S, Tanksley SD: Exploitation of Arabidopsis-tomato synteny to construct a high-resolution map of the ovatecontaining region in tomato chromosome 2. Genome 200I, 44(3):470-475.
42. Wikstrom N, Savolainen V, Chase MW: Evolution of the angiosperms: calibrating the family tree. Proc Biol Sci 200I, 268( (I 482):22II-2220.

43. Mudge J, Cannon SB, Kalo P, Oldroyd GE, Roe BA, Town CD, Young ND: Highly syntenic regions in the genomes of soybean, Medicago truncatula, and Arabidopsis thaliana. BMC Plant Biol 2005, 5: I5.

44. Mahé L, Combes MC, Lashermes P: Comparison between a coffee single copy chromosomal region and Arabidopsis duplicated counterparts evidenced high level synteny between the coffee genome and the ancestral Arabidopsis genome. Plant Mol Biol 2007, 64(6):699-7II.

45. Cannon SB, Sterck L, Rombauts S, Sato S, Cheung F, Gouzy J, Wang $X$, Mudge J, Vasdewani J, Schiex T, Spannagl M, Monaghan E, Nicholson C, Humphray SJ, Schoof H, Mayer KF, Rogers J, Quetier F, Oldroyd GE, Debelle F, Cook DR, Retzel EF, Roe BA, Town CD, Tabata $S$, Peer $Y$ Van de, Young ND: Legume genome evolution viewed through the Medicago truncatula and Lotus japonicus genomes. Proc Natl Acad Sci USA 2006, $103(40):$ I 4959 - I 4964

46. Rajesh PN, O'Bleness M, Roe BA, Muehlbauer FJ: Analysis of genome organization, composition and microsynteny using 500 kb BAC sequences in chickpea. Theor Appl Genet 2008, I I 7(3):449-458.

47. Velasco R, Zharkikh A, Troggio M, Cartwright DA, Cestaro A, Pruss $D$, Pindo M, Fitzgerald LM, Vezzulli S, Reid J, Malacarne G, lliev D, Coppola G, Wardell B, Micheletti D, Macalma T, Facci M, Mitchell JT, Perazzolli M, Eldredge G, Gatto P, Oyzerski R, Moretto M, Gutin N, Stefanini M, Chen Y, Segala C, Davenport C, Dematte L, Mraz A, Battilana J, Stormo K, Costa F, Tao Q, Si-Ammour A, Harkins T, Lackey A, Perbost C, Taillon B, Stella A, Solovyev V, Fawcett JA, Sterck L, Vandepoele K, Grando SM, Toppo S, Moser C, Lanchbury J, Bogden R, Skolnick M, Sgaramella V, Bhatnagar SK, Fontana P, Gutin A, Peer $Y$ Van de, Salamini $F$, Viola R: A high quality draft consensus sequence of the genome of a heterozygous grapevine variety. PLOS ONE 2007, 2(I 2):el326.

48. Wicker T, Yahiaoui N, Guyot R, Schlagenhauf E, Liu ZD, Dubcovsky J, Keller B: Rapid genome divergence at orthologous low molecular weight glutenin loci of the $A$ and $A m$ genomes of wheat. Plant Cell 2003, I5(5): I I86- I I 97.

49. Jansen RK, Kaittanis C, Saski C, Lee SB, Tomkins J, Alverson AJ, Daniell H: Phylogenetic analyses of Vitis (Vitaceae) based on complete chloroplast genome sequences: effects of taxon sampling and phylogenetic methods on resolving relationships among rosids. BMC Evol Biol 2006, 6:32.

50. Gerlach WL, Bedbrook JR: Cloning and characterization of ribosomal RNA genes from wheat and barley. Nucleic Acids Res 1979, 7(7): 1869-1885.

51. Ewing B, Hillier L, WendI MC, Green P: Base-calling of automated sequencer traces using phred. I. Accuracy assessment. Genome Res 1998, 8(3): 175-185.

52. Poncet V, Rondeau M, Tranchant C, Cayrel A, Hamon S, de Kochko A, Hamon P: SSR mining in coffee tree EST databases: potential use of EST-SSRs as markers for the Coffea genus. Mol Genet Genomics 2006, 276(5):436-449.

53. Poncet V, Hamon P, Minier J, Carasco C, Hamon S, Noirot M: SSR cross-amplification and variation within coffee trees (Coffea spp.). Genome 2004, 47(6): $107|-108|$.

54. Coulibaly I, Revol B, Noirot M, Poncet V, Lorieux M, CarascoLacombe C, Minier J, Dufour M, Hamon P: AFLP and SSR polymorphism in a Coffea interspecific backcross progeny [(C. heterocalyx $\times$ C. canephora) $\times$ C. canephora $]$. Theor Appl Genet 2003, I07(6): I I 148-II55.

55. Lander ES, Green P, Abrahamson J, Barlow A, Daly MJ, Lincoln SE, Newburg L: MAPMAKER: an interactive computer package for constructing primary genetic linkage maps of experimental and natural populations. Genomics 1987, I(2): 174-I8I.

56. Lincoln SE, Lander ES: Systematic detection of errors in genetic linkage data. Genomics 1992, I4(3):604-610.

57. Altschul SF, Madden TL, Schaffer AA, Zhang J, Zhang Z, Miller W, Lipman DJ: Gapped BLAST and PSI-BLAST: a new generation of protein database search programs. Nucleic Acids Res 1997, 25(I 7):3389-3402.

58. Salamov AA, Solovyev VV: Ab initio gene finding in Drosophila genomic DNA. Genome Res 2000, 10(4):516-522. 
59. Rice P, Longden I, Bleasby A: EMBOSS: the European Molecular Biology Open Software Suite. Trends Genet 2000, 16(6):276-277.

60. Rutherford K, Parkhill J, Crook J, Horsnell T, Rice P, Rajandream MA, Barrell B: Artemis: sequence visualization and annotation. Bioinformatics 2000, 16(10):944-945.

61. Sonnhammer EL, Durbin R: A dot-matrix program with dynamic threshold control suited for genomic DNA and protein sequence analysis. Gene 1995, I67(I-2):GCI-I0.

62. Mahesh V, Rakotomalala JJ, Le Gal L, Vigne H, de Kochko A, Hamon $S$, Noirot M, Campa C: Isolation and genetic mapping of a Coffea canephora phenylalanine ammonia-lyase gene (CcPALI) and its involvement in the accumulation of caffeoyl quinic acids. Plant Cell Rep 2006, 25(9):986-992.

Publish with Bio Med Central and every scientist can read your work free of charge

"BioMed Central will be the most significant development for disseminating the results of biomedical research in our lifetime. "

Sir Paul Nurse, Cancer Research UK

Your research papers will be:

- available free of charge to the entire biomedical community

- peer reviewed and published immediately upon acceptance

- cited in PubMed and archived on PubMed Central

- yours - you keep the copyright

Submit your manuscript here:

http://www.biomedcentral.com/info/publishing_adv.asp
BiolMedcentral 